\title{
THE ROLE AND PROBLEMS OF SMALL BUSINESS
}

\author{
EMERSON P. SCEMmT*
}

The phrase "small business" has become loaded with emotional overtones. Everyone appears to be for it. Numerous private associations have been formed to promote its welfare. Recently one of the leftist weeklies issued a special supplement on post-war planning: A Plan on Which Labor, Farmers and Small Business Can Unite. Thousands of books, brochures, leaflets, and articles have been written extolling its virtues and suggesting ways and means for assuring its survival and expansion.

Both the United States Senate and the House have created special small business committees. Early in World War II, the President of the United States created the Smaller War Plants Corporation. Special small business loan provisions were incorporated in the G. I. Bill of Rights, as enacted in 1944. The Department of Commerce has created a special unit to promote small business but, so far, has not found any formula for doing things for small business which would differ from what might be done generally by government for business. In the past decade, over four hundred bills have been introduced in Congress to help small business.

Yet, there is no commonly accepted definition of small business or statement of what the problem really is. This article is designed to throw some light on the problem and to provide the necessary background for subsequent discussion.

\section{What Is Smail Business?}

The political character of the "problem" of small business is suggested by Maury Maverick's definition: Any business which cannot afford a lobbyist in Washington. One study of the Department of Labor includes any firm which is below the average in number of employees for its industry.

The average man, when he uses the term "small business" probably means almost any type of business locally owned and operated in which the owner is the "boss" and actually is in charge of operations; he may be in business for himself or he may have a few employees associated with him. Popularly, the concept seems to be associated with "individual" enterprise.

- A.B., 1923, North Central College; M.A., I924, Toronto University; Ph.D., 1935, University of Wisconsin. On leave from the University of Minnesota, now serving as Director of the Economic Research Department, Chamber of Commerce of the U. S. A. Editor: MAN AND Society (1937). Author: Industrial Relations in URban Transportation (1937); Old Age Security (1936); Economics of Public Utilities (1940); and numerous articles and brochures. Editor: American Economic Security (1944-to date). Editorial Council, Journar of Land and Public Uthlity Economics. Member: Advisory Committee on Economics to Committee on International Policy (Carnegie Endowment). Chairman: Manitoba Rural Electrification Enquiry Commission. 
Among businessmen themselves, there is no clear-cut conception of what is meant by small business. Most of them use the phrase loosely with its meaning shifting as different problems or different segments of the economy come under review. Thus a retail store with an investment of $\$ 50,000$ may have no difficulty in securing adequate capital, while a manufacturing establishment of the same size may have great difficulty, because of the much greater risk due to the marketing problem. Only a very small fraction of small businessmen favor any special treatment for their group.

The Bureau of Foreign and Domestic Commerce has defined small business to include: manufacturing plants with roo employees or less; wholesale establishments with less than $\$ 200,000$ annual net sales; retail stores, service establishments, hotels, places of amusement and construction companies, with annual net sales or receipts of less than $\$ 50,000$. Obviously, these definitions are rigid and arbitrary but if comparisons with other countries or other times are to be made, we must have some bench mark. Therefore, in the following discussion, when the phrase "small business" is used, it will be used in the sense in which the Bureau defines the term, unless otherwise indicated.

\section{The Role of Small Business}

Our economic system embraces several millions of distinct and separate businesses producing hundreds of thousands of different products and providing many thousands of different services. In 1939, we had 6 million farmers in business. In addition, we had 3 million establishments in manufacturing, distribution and in the various service establishments as shown by the accompanying tabulation.

This table shows that over $92 \%$ of our business establishments were classified as small business, indicating the fallacy of the notion that the man with a little capital has no place in our society. It shows that, not including agriculture, we had 3 million separate establishments in business. For every 44 people in the country

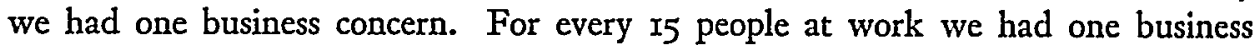
establishment and thus about every fifteenth man has a chance to run his own business.

Manufacturing is commonly thought of as the place where little business does not have much chance. Yet these figures show that nearly 169,000 concerns or $92 \%$ of all manufacturing concerns had roo employees or less. The table would suggest that in service establishments the man with small capital has the best chance, because here nearly $99 \%$ of all businesses are classed as small. Over a million and a half small retail establishments were in existence.

About $45 \%$ of the employees of the foregoing 3 million establishments were working for small business. Even in manufacturing, $30 \%$ of the workers made their living in small factories, that is, in plants with Ioo employees or less.

The small concerns, although constituting over $90 \%$ of all concerns and employing about $45 \%$ of the workers, were responsible for only $34 \%$ of the value of the 
products or services turned out. In the case of manufacturing, about $30 \%$ of the product came from small plants; in the case of retailing, the small establishments were responsible for about $42 \%$ of the sales and in the case of service establishments, the figure was $66 \%$.

\section{Proportion of Small Business to Total in the United States by Number} of Establishments*

I939

\begin{tabular}{|c|c|c|c|}
\hline Industry or Trade & $\begin{array}{c}\text { Total for } \\
\text { United } \\
\text { States** }\end{array}$ & $\begin{array}{c}\text { Small } \\
\text { Business }\end{array}$ & $\begin{array}{c}\text { Ratio of } \\
\text { Small } \\
\text { Business } \\
\text { to U. S. } \\
\text { Total }\end{array}$ \\
\hline Manufacturing $\ldots \ldots \ldots \ldots \ldots \ldots \ldots \ldots \ldots$ & 184,230 & $I 68,8 x_{4}$ & 9 г.6 \\
\hline Wholesaling...$\ldots \ldots$ & 92,794 & $7 \mathrm{I}, 68 \mathrm{I}$ & 77.2 \\
\hline Retailing & $1,770,355$ & $\mathrm{I}, 6 \mathrm{I} 4,3 \mathrm{IO}$ & 91.2 \\
\hline Service Establishment & 646,028 & $637,5^{8} 5$ & 98.7 \\
\hline Hotels ..... & 27,987 & 25,224 & 90.1 \\
\hline Construction $\ldots \ldots \ldots \ldots \ldots \ldots \ldots \ldots \ldots \ldots \ldots \ldots$ & 215,056 & 200,307 & 93.I \\
\hline Places of Amusement $\ldots \ldots \ldots \ldots \ldots \ldots \ldots$ & 44,917 & $40,35^{1}$ & 89.8 \\
\hline Mining $\quad \ldots \ldots \ldots \ldots \ldots \ldots \ldots \ldots \ldots \ldots \ldots \ldots \ldots \ldots \ldots \ldots \ldots$ & I5,393 & 13,738 & $89 \cdot 3$ \\
\hline Transportation & & & \\
\hline Steam Railway & 850 & 428 & 50.3 \\
\hline Motor Carriers ..... & $27,72 I$ & 26,406 & $95 \cdot 3$ \\
\hline Communication & & & \\
\hline Telephone & 6,694 & 5,848 & 87.4 \\
\hline Radio Broadcasting $\ldots \ldots \ldots \ldots \ldots \ldots \ldots$ & 705 & $4^{89}$ & 69.4 \\
\hline Banking $\quad \ldots \ldots \ldots \ldots \ldots \ldots \ldots \ldots \ldots \ldots \ldots \ldots \ldots \ldots$ & I 4,964 & 13,529 & 90.4 \\
\hline Total** & 694 & 2,8 I 8,7 го & 92.5 \\
\hline
\end{tabular}

From 1909 to 1939 , population increased by $44 \%$ while the number of manufacturing establishments increased $7 \%$. Thus the number of establishments did not expand in proportion to population growth, but the number did expand. In this same period, the value of the product of small business increased 2.3 times although the value of product of large business increased 3.3 .times. Thus it seems that in

\footnotetext{
- Small Business: Manufacturing and mining plants with 100 employees or less (all manufacturing plants with value of product less than $\$ 5,000$ are classified under service establishments by the Census); wholesale establishments with less than $\$ 200,000$ annual net sales volume (includes wholesale merchants and industrial distributors and does not include agents, brokers, assemblers, manufacturers' sales offices, etc.); retail stores, service establishments, hotels, places of amusement, and construction establishments with annual net sales or receipts of less than $\$ 50,000$; steam railways classes II and III, motor carriers classes II and III, telephone systems and lines, companies with annual revenue of less than $\$ 10,000$; radio broadeasting stations with annual revenues under $\$ 100,000$; banks with deposits under $\$ 5,000,000$. Source: Computed from 1939 Censuses of Manufactures and Business by Bureau of Foreign and Domestic Commerce, U. S. Dept. of Commerce.

* Total does not include such activities as insurance, brokerage, labor unions, professional and real estate because of inadequate data. Agriculture is not included in the above table; in 1939 there were $5,969,000$ farms in the United States, of which $5,655,000$ or $94.7 \%$ were small. All farms with value of products less than $\$ 4,000$ per year were classed small.
} 
this 30-year period small business has grown in both numbers and value of output, although its share of total business has been shrinking.

In $1939,92 \%$ of all stores were independent and only $7 \%$ were chain stores, although the latter did about $22 \%$ of the total volume of business. In 19r9, chain stores did $4 \%$ of the business and the expansion continued rapidly until it reached a figure of $25 \%$ in 1933 . Since that time, the proportion of business done by chains has shown a slight decline.

Of the 184,230 manufacturing establishments in $1939,8,300$ were one-man affairs; that is, they had no employees, the owner working by himself-small machine shops, broom factories, cigar factories, etc.- - examples of individual enterprise. These businessmen carry on the functions of labor, management, salesman-all by the same person. Some of them probably were just getting started when the census was taken. Some may fail or merge with other businesses. Some will grow to be larger concerns in subsequent years.

Nearly 76,000 manufacturing concerns had from I to 5 employees each, while another 49,000 had from 6 to 20 workers. Only i76 establishments had over 2,500 employees.

\section{The War and SMall Business}

The Senate Small Business Committee reported that one sixth of all businesses have disappeared during the war. ${ }^{1}$ About the same time, we were told that small business has prospered during the war as never before. There is truth in both statements.

While data on the birth and discontinuance of businesses are none too reliable, it appears that by 1944 there were about 225,000 fewer firms in operation than in 1929, and about 475,000 fewer than in I939. Losses since 1939 were greatest in retail trade, service industries and contract construction. The only major industrial groups to gain were manufacturing, mining and quarrying. ${ }^{2}$

Many thousands of small businesses closed because their owners were drafted or found jobs in war industries which remunerated them better than did their own businesses. Other small businesses, filling stations and automobile dealers, for example, closed because of the shortages of goods. When the war is over, many of these former businessmen will reopen their mines, shops and stores.

The following table shows that, of the firms which did survive the war, the smaller ones prospered substantially more than did the larger ones from I940 to 1943. This is true of manufacturing, wholesaling as well as retailing. It is true whether one considers the increase in 1943 profits over the I940 figure, or whether one considers the net profit increase as a percentage of the owner's net investment. Since these figures are based on a limited sample and indicate average performance of the various groups, it scarcely needs saying that individual companies in many cases did not experience the same trend.

\footnotetext{
${ }^{1}$ Senate Small Business Committee-Its Record and Outzook (Progress Report) Sen. Commitice Print No. I, 79th Cong., Ist Sess. (Jan., 1945).

${ }^{2}$ Department of Commerce, and National Industrial Conference Board reports.
} 
Earnings of Small and Large Business ${ }^{3}$

\begin{tabular}{|c|c|c|c|c|c|c|c|c|c|}
\hline \multirow{3}{*}{$\begin{array}{l}\text { Asset Size } \\
\text { (In Dollars) }\end{array}$} & \multicolumn{3}{|c|}{$\begin{array}{c}\text { Percentage Increase in Net } \\
\text { Profit (After Taxes) } 1940 \text { to } 1943\end{array}$} & \multicolumn{6}{|c|}{$\begin{array}{c}\text { Net Profit (After Taxes) } \\
\text { As Percentage of Net Worth }\end{array}$} \\
\hline & \multirow{2}{*}{$\begin{array}{c}\text { Manufac- } \\
\text { turing }\end{array}$} & \multirow{2}{*}{$\begin{array}{c}\text { Wholesale } \\
\text { Trade }\end{array}$} & \multirow{2}{*}{$\begin{array}{l}\text { Retail } \\
\text { Trade }\end{array}$} & \multicolumn{2}{|c|}{$\begin{array}{l}\text { Manufac- } \\
\text { turing }\end{array}$} & \multicolumn{2}{|c|}{$\begin{array}{l}\text { Wholesale } \\
\text { Trade }\end{array}$} & \multicolumn{2}{|c|}{$\begin{array}{l}\text { Retail } \\
\text { Trade }\end{array}$} \\
\hline & & & & 1940 & 1943 & 1940 & 1943 & 1940 & 1943 \\
\hline $\begin{array}{l}\text { Under } 50,000 \ldots \ldots \\
50,000 \text { to } 100,000 \ldots \\
100,000 \text { to } 250,000 \ldots\end{array}$ & $\begin{array}{l}410 \\
574 \\
178\end{array}$ & $\begin{array}{l}109 \\
197 \\
132\end{array}$ & $\begin{array}{r}135 \\
106 \\
97\end{array}$ & $\begin{array}{r}7.7 \\
10.7 \\
10.3\end{array}$ & $\begin{array}{l}28.3 \\
41.4 \\
20.8\end{array}$ & $\begin{array}{r}9.0 \\
14.2 \\
10.2\end{array}$ & $\begin{array}{l}12.2 \\
28.0 \\
17.9\end{array}$ & \begin{tabular}{r|}
24.2 \\
12.5 \\
9.0
\end{tabular} & $\begin{array}{l}41.0 \\
19.3 \\
14.8\end{array}$ \\
\hline $\begin{array}{l}\text { Under } 1 / 4 \text { million.... } \\
1 / 4 \text { to } 1 \text { million..... } \\
1 \text { to } 5 \text { million..... } \\
5 \text { to } 10 \text { million..... } \\
10 \text { million and over. }\end{array}$ & $\begin{array}{r}225 \\
212 \\
53 \\
19 \\
4\end{array}$ & $\begin{array}{c}144 \\
123 \\
72 \\
9 \\
111(a)\end{array}$ & $\begin{array}{r}102 \\
98 \\
65 \\
96 \\
19\end{array}$ & $\begin{array}{r}10.2 \\
7.0 \\
9.5 \\
10.5 \\
10.4\end{array}$ & $\begin{array}{r}23.7 \\
17.0 \\
11.6 \\
10.2 \\
9.6\end{array}$ & $\begin{array}{r}10.7 \\
7.7 \\
8.0 \\
8.8 \\
4.1\end{array}$ & $\begin{array}{r}19.4 \\
14.2 \\
11.5 \\
8.3 \\
8.1\end{array}$ & $\begin{array}{r}10.0 \\
8.1 \\
7.7 \\
7.3 \\
8.7\end{array}$ & $\begin{array}{r}16.6 \\
13.0 \\
10.8 \\
12.7 \\
9.4\end{array}$ \\
\hline
\end{tabular}

(a) Represents less than five companies.

\section{Why All This Devotion to Small Business?}

Much of the concern over the alleged plight of small business is purely political. At times attempts are made to foster a cleavage between small and big business. Again it arises from the complaints of small business against the growth of federal control and the burden of paper work imposed by the federal bureaus, both during and before the war. It is also due to a vague feeling that the preservation of democracy and liberty are dependent, in part, upon the survival of a host of small, thriving enterprises spread across the country.

That a free, voluntary society depends upon a diffusion of power, the maintenance of opportunity and the avoidance of undue "bigness," both in government and in private life, has been widely asserted throughout history. In the fourth century B.C., Aristotle said:

"The best political community is formed by citizens of the middle class. Those States are likely to be well administered in which the middle class is large, the larger if possible than both the other classes, or at any rate than either singly; for the addition of the middle class turns the scale and prevents either of the extremes from being dominant" (Politics, Book II).

In the nineteenth century Lord Acton said: "All power corrupts and absolute power corrupts absolutely." In I862 Congress passed the Homestead Act under which a typical American philosophy was given expression. Under the law, any one could secure, virtually free of charge, I6o acres of land out of which he could carve his own home and make his living. Instead of allowing the land to fall into the hands of a few large landlords or plantations owners, the purpose was to divide up the great heritage which was ours. As a result, we have today six million farms, owned by an equal number of persons or families. Millions of farmers are owners of livestock, machinery and land. Farming in the United States is

\footnotetext{
${ }^{3}$ Dirks, Wartime Earnings of Small Business (Jan., 1945) Fed. Res. BuLl. I6-23.
} 
small business for the most part. While one-third of the farms are tenant-operated, may tenant farmers of today will be owners tomorrow.

A generation later, in 1890 , Congress passed the Sherman Antitrust law designed to prevent monopoly, undue bigness, and to keep the doors of opportunity open.

If Aristotle and Lord Acton were right and if American anti-monopoly policy as to both agriculture and other industries was right, it does not require much imagination to see that it is important to have a goodly portion of our economy occupied by small business.

\section{Political and Social Importance of Small Business}

One of the prime essentials of a democracy is this equality of opportunity. The young man just out of school should have the opportunity to carve out for himself a place in the economic life of the community. If business were confined to a few large companies in every community, the opportunities for self-employment, self-direction and self-realization would be reduced. The man with ideas, ambition and small capital would not have an opportunity to use his capital, try out his ideas and satisfy his ambition.

Hitler, in his rise to power, made vast promises to the ambitious youth of the land. He knew their longings and promised to fulfill them. For example, he promised to break up the large department stores and provide thousands of opportunities for the rise of small stores-a promise never fulfilled. Many of them had felt frustrated and supported Hitler because of the promises he made for individual opportunity. If we are to avoid having some demagogue appeal to our youth to serve his own rise to power, we must be certain that opportunities are open. Therefore, small business has a fundamental place in a liberal democracy.

By and large, it is the combined effect of the numerous small businesses in the local community which make that community. The payrolls and other earnings of the many enterprises support the schools, the churches, the government services, the recreational and cultural activities of the community. If these businesses are not prosperous the schools will be inadequately financed, the churches will languish and other desirable community activities will be dulled and unstimulating. Flourishing small businesses activate the life, the thinking, the recreational and cultural interests of the people in the community. A multitude of small businesses in manufacturing, service and distribution lend color and variety to the community.

\section{Economic Importance of SMall Business}

One of the great values of a free society is free consumer choice. The rich and the poor, the young and the old, the educated and uneducated, the farmer, craftsman, professional man and businessman-each can buy according to his means and his tastes. Unquestionably, one of the great and enduring values of a modern free society is the enormous range of commodities and services available to the consumer. If we had only a few large companies bent on efficiency and mass production, there can be no question but that the range of goods and services made avail- 
able would be reduced. Having a gxeat variety of producers in competition with one another, the tendency for commodities and services to multiply in number, design and quality is great.

With nearly 200,000 different manufacturers and the hundreds of thousands of service establishments each competing for the market, progress is almost inevitable. Under the stress of competition, prices tend to be lowered, quality tends to improve, and in order to penetrate the market each producer endeavors to give high value for the money.

Out of this multitudinous effort come new ideas, new products, improved raw material and better service. An official of General Motors Corporation stated that if that company secured a monopoly of the production of automobiles, there would be fewer cars produced within ten years. By having a host of small businessmen, each striving to get ahead and many succeeding, the opportunity for any one business to attain a monopoly is greatly reduced or eliminated. Each acts as a spur to the others. The small business of today may become the large business of tomorrow.

However, we should not attempt to keep alive all businesses. Freedom and democracy imply the freedom to take a chance, to succeed and, indeed, to fail. A free society provides freedom of opportunity but does not guarantee success to all who enter. Success depends primarily on management ability, although, in practice, luck or chance factors often play a role in the outcome.

The small business is the economic seed bed from which rise the majority of new ideas, new methods and the inventions of the nation. The United States Patent Office records reveal that of all the patents issued between rg2I and 1938, $43 \%$ went to individuals and $34.5 \%$ to 17,500 small and medium-sized enterprises. In other words, individuals, small and medium concerns accounted for about $77 \%$ of all patents issued within this period. Clearly, from an economic viewpoint, the small business and the enterprise of the individual are of the highest importance to our well-being. Mr. F. B. Jewett, president of the Bell Laboratories, Inc., stated:

"Fundamental patents which mark big changes in the arts are more likely to come from the outside than from the inside. I think, in the majority of cases, the chances are ten to one that the fundamental idea will come from outside the big laboratories."

We do not want to minimize the great achievement of our great motor car, electric, chemical and other companies, because all of them have large, flourishing laboratories constantly bringing out new products, making improvements, finding new uses for raw materials and making a great contribution to our welfare. Nevertheless, in trying to think of the place of small business in our economy, it is important to recognize that the small business-while frequently less efficient than the large business-does make a great contribution, partly because there are so many of these small units. Many of them barely hang on, others disappear; but out of the great number striving to get ahead, there is a sizable fraction which constantly brings forth new ideas, new products and new methods. In short, there is a definite and useful place for both large and small business in a free economy. 
A director of a railroad car manufacturing concern stated that the war has shown him how utterly dependent upon small business his company is for the supply of numerous small parts which it would not pay the company to manufacture itself. No refrigerator manufacturer and no radio manufacturer, for example, produces all the parts which go into the final product. Rather, they rely on a host of small plants each of which specializes in the making of one or more small parts. The small plant, by catering to the needs of a host of other manufacturers, is enabled to obtain a volume of production which cuts its costs below the costs of the manufacturers if each of the latter tried to make all the essential parts for the final product.

Another advantage of having many businesses in a community is that the worker has open to him numerous employment offers. If he does not like the policy of one employer or crosses swords with his foreman or plant superintendent, he can secure a job elsewhere. If our policies encourage competition and the establishment of many small employers, this opens up many new employment offers. No one is restricted and opportunities are multiplied.

\section{New Investment Required to Create Jobs}

Ours is a capitalistic society; it requires approximately $\$ 5,000$ investment, on the average, in plant, tools, office buildings and other equipment, etc., to put one man to work. In railroad transportation, it requires $\$ 25,000$, in steel about the same figure, in manufacturing as a whole about $\$ 6,300$, in retailing about $\$ 5,000$. Our labor supply is increasing at the rate of about 700,000 (net) young workers each year, after allowing for those who die, retire or quit.

If we are to prevent mass unemployment and provide jobs for our young people who, for the first time, enter the labor market each year, we must have a high rate of new investment in job-creating facilities. If we establish firmly a large number of new businesses year after year, this is the best assurance that a plentiful supply of new job opportunities are created. American democracy must continue as a living, vital, reality by opening new opportunities for jobs and for business. Without a steady growth of new businesses and new employers, we are not likely to have adequate job opportunities. We must govern our policies so that we place a premium on the man who makes his living by giving jobs. This is important for the post-war. An employer is one who provides employment; we should encourage him and give him an honored place in our democracy.

\section{Limitations and Difficulties of Small Business}

Small business is in competition with large-scale business. Within limits, it is true that the larger the business or the greater the volume, the more practical it is to subdivide the work and get the advantages of mass production. Small-scale concerns may be able to subdivide work somewhat but rarely to the degree possible in larger operations. This limitation applies not merely to plant operations but also to management, sales, advertising, purchasing, legal, engineering and other aspects 
of the operation. A large plant can hire, for example, the services of a full-time engineer or attorney, who becomes thoroughly familiar with all the problems and operations. A smaller concern probably hires this talent as it needs it and, therefore, probably does not secure as effective service. A large concern has expert accountants, financial managers, buyers, etc.

In a smaller concern, the general manager may have to perform, or at least closely supervise, all these aspects. He is less likely to be a specialist and a small concern is apt to suffer from the difficulties embodied in the adage, "Jack of all trades and master of none." Of course, for many small concerns this is an exaggeration because many of them are very efficient.

A large filling station with a dozen employees, to use a familiar example, can hire persons for specific purposes: handling the gasoline pumps, lubrication, washing, tire repair, etc. Each person becomes thoroughly familiar with the tools he uses, the peculiarities of the customers with respect to each service and, if the volume of business is large, he can work at his specialized tasks continuously and efficiently. In smaller stations, one or two persons must constantly shift from task to task, much time is wasted, and they may never develop the proficiency of the workers in the larger establishment.

What has been said about the filling station may apply to other businesses; "smallness" has its limitations.

Large size brings a technical advantage. If we compare the building and equipment of two companies producing identical products, one of which turns out $r, 000$ units per week and another turns out 500 per week, we will find that the investment in plant and equipment of the large producer is not twice as large as that of the smaller producer. If each needs an engine for power, let us say 1,000 horsepower and 500 horsepower, respectively, it will be found that the big engine does not contain twice as much steel, copper, and other metals as the smaller engine. Thus, the large producer gets his power equipment cheaper per unit of output than does the smaller producer. Similarly, both producers may have a plant covering an area of 1,000 square yards, but the large producer has four stories to his building, while the smaller company has two stories, yet, the same sized roof will cover both buildings. A quart metal container does not contain twice as much metal as a pint container. In short, size brings a host of engineering economies which are not possible to the smaller concern. These are technical handicaps which may have to be overcome by all other means open to the small company.

The greatest handicap of small manufacturers lies not primarily in physical production but in marketing, advertising and salesmanship. A producer with a volume sufficient to warrant the use of national advertising, the development of a nationwide sales force, and establishment of his own dealer and retail outlets has an advantage over the producer who must rely on inferior advertising media, on wholesalers and retailers who also handle the lines of his competitors and who in general, because of the smallness of the enterprise, cannot make a continuous, widespread and 
forceful impression on the buyer. The mail order houses and the chain stores, while at times thought of as injurious to the small business, nevertheless do provide outlets for the product of thousands of small producers who, because of the existence of these large distributors, do not need an elaborate selling organization. In a number of cases small producers have combined in establishing common sales organizations and cooperating in sales efforts in other respects. These techniques merit further study and exploration.

Nevertheless, we all know that small filling stations do survive in competition with large ones. We all know that the small store continues to meet its customers' needs even though a few blocks away a supermarket may be in operation. All this suggests that under a modern society many factors govern the origin and survival of business units. Matters of location, convenience, the personality of the owner and employees, the ability to cater to special needs-all these help to explain the survival of many, many small businesses.

In some instances the small concern, in closer touch with its employees and customers, is able to improve its own operations and its service. Small business, although finding it difficult to comply with rules and regulations imposed from without, is able to change, to adapt itself to new conditions and to enter new or unusual lines because, being small, this smallness offers a high degree of flexibility.

A large organization with branches, sales offices and other connections all over the country is much more likely to follow a given policy once it is adopted. Small business, with its relatively light overhead costs and its ability to experiment on a small local scale, frequently has an advantage over a larger unit. It is this ability to experiment, to adapt itself and to change which makes small business so important in the economy as a whole.

Furthermore, while large size brings advantages, it also has its disadvantages. Once an establishment grows beyond a certain size, the relations between management and employees may become less personal and morale may suffer. Wastes may go undetected; inefficiencies in the handling of materials, due to lack of adequate supervision, may more than offset the gains from specialization of labor. Indeed, these factors are the chief explanation why the biggest companies do not keep on growing indefinitely large and absorb the whole market.

Moreover, mass production is adaptable only to a limited number of products and generally not at all to service enterprises. For example, the entire consuming public may be willing to buy only roo copies of a particular hat, or dress or display case. Many service trades and manufacturers cater to specific needs and this may require custom-built products and specialized services. In these cases, large-scale operations are poorly adapted to meet individual needs and the small business has a special opportunity.

While a larger proportion of all business is being done by large concerns, there is no evidence that small concerns will disappear from the scene except perhaps in a few industries, such as steel and automobile manufacturing. But, even here, we 
cannot be certain. For example, while three motor car producers make more than $80 \%$ of all cars, each of these producers relies upon hundreds of suppliers or subcontractors to make parts. In turn, each large producer relies on thousands of wholesalers and retailers to help in disposing of the product.

\section{Can Small Bustness Be Helped?}

America has never been short of people who wanted to establish their own business-indeed, the desire to be one's own boss, to be in business for oneself, is almost universal. Given favorable conditions such as during a period of prosperity, the birth rate of new businesses rises substantially. But the number of failures during such periods rises almost as rapidly.

This suggests that small businesses in their competitive struggles are themselves in part responsible for the difficulties of survival. If this is true, serious question arises as to what can be done especially for them by private or governmental effort. That is, if some governmental agency provides special services to enable small businesses to originate and grow-would not the resultant increase in the number of businesses, each trying to get its share of the available business volume, leave the situation just about where it was before the effort to help them was made?

To put the matter in another way: By giving each small businessman better advice, better management tools, tax rebates or other special or regular advantageswhile all these aids may reduce costs and raise efficiency-they also tend under competition to reduce prices and thus may tend to leave the various competitors in about the same relative positions as before. Some will survive, some will grow, but many will be eliminated unless these aids result in a larger total volume of business to be shared among the businesses in the field.

The foregoing raises a critical point and all attempts to help small business should be judged in terms of it. Certainly some obstacles can be removed and possibly some positive steps can be taken. But, evidently, the greatest aid to small business must be attained by bringing about those conditions which will stimulate business in general and not just little business.

\section{Policies of Big Business}

Because of the importance of small business big business should give full support to the effective enforcement of our antitrust laws, should disavow unfair and socially undesirable competitive practices. Unfair competive practices are difficult to define, but one example might be cited-cutting prices below cost by the large concern in a given area merely to eliminate a small competitor with a view to restoring prices as soon as the small concern is liquidated.

Big business has been accused of creating a type of collectivism of its ownacquiring patents, taking on new lines, taking over a whole field, integrating operations from raw materials to consumer. These great aggregates of capital and know-how have been the source of American strength in both peace and war; few persons would break up these large units. In their expansion programs, however, 
the large concerns should make every effort to avoid taking unfair advantage of the smaller units and should in so far as practical take positive steps ${ }^{4}$ to see that many smaller concerns are kept alive and prosperous. This will not only add to the strength of the nation but will also reduce the opportunities of the demagogue to bait the larger concerns.

\section{Special Aid to Small Business}

While many modern tendencies favor large business, an enormous amount of effort has been made in the last two decades to discover the handicaps of small business and find remedies for its difficulties. The Department of Commerce of the national government has created a Small Business Unit in charge of a staff of people in full sympathy with the problems of small business. In 1943, this unit published a summary of 390 (note the large number!) bills introduced in Congress from $r 933$ to $\mathrm{r} 943$ to help small business. Twenty-six of these bills were passed by Congress.

Some are designed to help raise capital for small business from both private and public sources. The U. S. House and Senate have set up special committees, under Representative Wright Patman and Senator James E. Murray, respectively, to study the problems of small business. Both committees carry on continuous study and research, hold hearings, and make recommendations to Congress in the form of remedial and corrective legislation. These committees have the dual task of aiding small business enterprises to make adjustments to wartime conditions, as well as the broader problem of determining means of preserving small business as an essential part of our peacetime economy.

One bill which was passed was designed to reduce the complexities of government reports required of all businesses, but which bore very heavily upon small business because the smaller units do not always have adequate staffs of attorneys, accountants, etc. Fifty-four bills have been introduced to sponsor business and industry research, some of which would require or stimulate cooperative research with state universities in both technical and business administration matters.

It is generally agreed that government controls, regulations and rules bear much more heavily upon small business than on larger units. The larger ones with more adequate reserves are more adaptable and flexible and find compliance easier.

Many people, however, question the wisdom of special exemptions on the ground that they are open to abuse (every one will strive to get the benefit of the exemption and escape the prohibition) and on the ground that all businesses should operate under the same "rules of the game" with special privileges to none. Once special privileges are provided, enormous pressures are built up to keep on expanding the coverage. $^{5}$

\footnotetext{
4 In one middle western city a number of large concerns entered an agreement to do technical research for a number of small businesses on a cost basis.

"The U. S. Senate Special Committee to Study Problems of American Small Business, in its January, 1945, Progress Report, supra footnote I, states, "In thus highlighting small business' role in American life it is not implied that this important segment of business should have any favored treatment at the hands of government. Nor does it need any" (p. 3).
} 
For this reason, proposals for any special privileges for small business should be carefully examined to be certain that they comply with the American conception of fair play, uniformity of treatment, equality of opportunity for all and special privilege to none. ${ }^{6}$

If small business has special difficulty of raising capital and new provisions are made to provide capital, every business should have access to this capital. If our present taxes on business discourage expansion and growth, we should provide proper relief for all business, on the theory that the able managers-even though in small business-will then have an opportunity to expand. If the government carries on special research it should be made available to all, on the assumption that the small units will probably have a high inducement to utilize the opportunity, while the larger units, although not barred from using it, nevertheless, will be capable of carrying on their own research and, in most instances, will do so.

An enormous number of voluntary business organizations have come into existence to promote business. These groups are open to small business and each organization is designed to promote the interests of its members. Thus, we have over 3,000 local chambers of commerce, 3,000 national and interstate trade associations, over 5,000 local trade associations, and many other groups such as the Chamber of Commerce of the United States of America, the National Association of Manufacturers, and others. In addition, there are hundreds of professional groups, such as chemists' and engineers' associations, etc.

Each group generally publishes a magazine keeping its members informed of new developments, new opportunities, methods of reducing costs, promoting business and removing obstacles. In addition, most groups issue special reports on specific subjects, have a consultation service, hold meetings and provide data and materials upon request. The small employer may not belong to as many groups as he might and, therefore, is not always placed in touch with the new as promptly as might be the case but every effort should be made to extend the services of these voluntary groups to the small business unit and considerable progress has been made in this direction.

In spite of the difficulties facing small business many such units are launched, thrive and grow. This has led some observers to believe that the key to the small business problem is better management; that is, businessmen who are more competent, more aggressive, more alert, better informed, so that they may become better managers. According to this diagnosis, the solution must be found in furnishing management with better tools for management. To this end, it is proposed in the Mead-Lee bill, pending in Congress, that the federal government provide a management consulting service for business. Consultants qualified in finance, purchasing, production, distribution and marketing, personnel, etc., would be stationed

\footnotetext{
${ }^{-}$Our federal income tax laws favor, chiefly for administrative reasons, companies with very small net income. Partnerships are favored over corporations since the latter are liable to taxation on company income and their stockholders are likewise liable for personal income taxes. Chain store taxcs are designed to aid small business but are open to question because they tend to penalize efficiency.
} 
throughout the country to provide on-the-spot advice and help in the solution of all problems. They would put the management in touch with all varieties of information and possible sources of information. This type of aid would be comparable to that now furnished, at great cost, to farmers in over 3,000 counties through the county agents and other agricultural services.

Another proposal is to have the federal government subsidize business research through the state universities on the same basis as agricultural research is now subsidized through the numerous agricultural stations and state universities throughout the country. Because of the great diversity of business and business problems, this analogy with agriculture has been questioned in some circles.

Some people see some danger in such proposals on the ground that they might lead to undue interference and control of business, but, if properly safeguarded, this danger can be avoided.

Another proposal relates to the supply of capital. Small businesses, because they frequently are not firmly established and have not grown by their own strength, may still have plans for new products, for promotion, etc., but lack capital. Government capital loaned to such enterprises might entail considerable dangers. Political pressures would inevitably play a role in determining which companies should secure loans and if the government has a stake in an enterprise it would also insist in having a voice in management, which might lead to undue invasion of a field in which government should not play a role according to our traditional conception of the place of government in the economy. Furthermore, what small business needs, primarily, is equity capital, rather than loan capital, and the government can scarcely be expected to furnish this.

A better solution may be found by having groups of banks, investment houses, and perhaps insurance companies set up special services for making loans to small business and buying stock in small companies. By pooling the risks and making a small insurance charge to cover the inevitable losses, much new venture capital could be furnished by private enterprise on a sound basis without getting our government involved in all sorts of ventures.

In the past 20 years some 15,000 local banks have disappeared. Either the banks, as such, or their officers supplied venture capital to local people with inventions, or ideas for new business. With the shrinkage in this source of capital, the financial aid for new business has been diminished. Savings have tended to be absorbed by government bonds, which type of investment normally does not lead to the creation of continuously self-sustaining job opportunities. With proper encouragement, through a revision of our system of business taxation, there is reason to believe that in hundred of communities local businessmen, people with funds or having access to funds, would be willing to subscribe to new stock issues for new or expanded concerns. Every substantial community might have a Venture Cap- 
ital, Inc., ${ }^{7}$ which would specialize in sifting proposals for new businesses or requests for new capital and would purchase shares in the proposed ventures if found such as to warrant some hope of success. This local sifting, appraisal and financing is highly desirable.

Only a small number of business concerns have profits year after year. Even in prosperous years, about one third of our corporations have no profits. The owners have to pocket the losses in the bad years and when profits do occur governments (both state and federal) take from $20 \%$ to $80 \%$ of the profits.

Under this situation, the new or small concern finds considerable difficulty in getting started or building up adequate working capital or capital for expansion. Thus, it has been proposed that business be allowed to carry forward losses so it would pay income tax on the average earnings for a period of say five years, rather than to have the government skim the cream in the few good years and force the owners to absorb the losses of the bad years.

\section{Conclusions}

On the importance of a high birth and survival rate for new business, there is no difference of opinion. The plight of small business, per se, has at times been exaggerated. The best answer to the problem, it appears, is not preferred or special treatment, but the development of a political and economic climate which is favorable to competive business and job-making in general. Under such conditions, small business will find a place for itself and will play a vigorous and important role in post-war America. This does not preclude the advisability of many specific steps by private and public groups, as suggested in subsequent articles in this symposium.

${ }^{7}$ Many local chambers of commerce have established such organizations. For descriptions and a partial list see: Chamber of Commerce of U. S., Community Industrial Financing Plans (mimeographed, undated but published in 1945). See also infra, this symposium, Stoddard, $A$ Regional Experiment in Practical Development of Industries, p. $36 \mathrm{r}$. 